\title{
Development of a Loop-Mediated Isothermal Amplification Assay for Rapid, Sensitive and Specific Detection of a Campylobacter jejuni Clone
}

\author{
Yan LUO $^{1,2)}$, Orhan SAHIN ${ }^{1)^{*}}$, Lei DAI ${ }^{1)}$, Rachel SIPPY1), Zuowei WU'1) and Qijing ZHANG ${ }^{1)}$ \\ 1) Department of Veterinary Microbiology and Preventive Medicine, Iowa State University, Ames, Iowa 50011, U.S.A. \\ 2) Laboratory of Microbiology, Dujiangyan Campus, Sichuan Agricultural University, Dujiangyan 611830 China
}

(Received 14 October 2011/Accepted 9 December 2011/Published online in J-STAGE 22 December 2011)

ABSTRACT. Loop-mediated isothermal amplification (LAMP) assay is a simple, rapid and specific detection method and has been used for detection and identification of different Campylobacter species. In this study, we develop a LAMP assay specific for detection of a particular clone (clone SA) of Campylobacter jejuni, associated with the vast majority of recent sheep abortions in the U.S. Using a set of specific primers for C. jejuni IA3902 (a clone SA isolate) and genomic DNA or boiled cell extract as template, the target DNA was amplified at $63^{\circ} \mathrm{C}$ for $50 \mathrm{~min}$ in a water bath. A positive reaction was identified visually as white precipitate or fluorescence under UV, and confirmed by gel electrophoresis. Detection limit of the assay was comparable to that of conventional PCR. The LAMP was shown to be specific for detection of clone SA when tested on a number of C. jejuni strains of different genetic backgrounds. Applicability of the LAMP assay for specific detection of clone SA was demonstrated in animal tissues experimentally infected with IA3902 or genetically diverse $C$. jejuni strains. Since clone SA is the predominant cause of sheep abortions in the U.S. and is a zoonotic pathogen, the LAMP assay may be a valuable detection tool in future epidemiological studies.

KEY WORDS: Campylobacter jejuni clone SA, detection, loop-mediated isothermal amplification, PCR.

doi: 10.1292/jvms.11-0462; J. Vet. Med. Sci. 74(5): 591-596, 2012

Rapid and reliable detection and identification of Campylobacter from clinical and environmental sources is of paramount significance in epidemiological studies. Several methods such as culture, biochemical assays and PCR-based assays have been developed for detection and identification of Campylobacter species [5, 9, 11, 12, 14]. Despite being effective and accurate, the bacterial culture and biochemical assays may require up to 4 days and thus are time-consuming. PCR-based assays are more rapid to identify Campylobacter species than bacterial culture and biochemical assays, but the requirement of sophisticated procedures and expensive equipments to detect the DNA targets may greatly restrict their application in clinical settings.

Recently, a rapid and simple assay named loop-mediated isothermal amplification (LAMP) [6] for the detection of C. jejuni $[16,18]$, Campylobacter coli $[16,18]$ and Campylobacter fetus $[17,19]$ has been developed. The LAMP assay is a highly specific strand displacement amplification method, using 4 to 6 different primers designed to 8 from 6 distinct regions of the target DNA sequence. Only one efficient DNA polymerase (Bst DNA polymerase) is required, the amplification reaction proceeds under a single and isothermal temperature (i.e., $60-65^{\circ} \mathrm{C}$ ), and it has a high amplification efficiency. Moreover, the LAMP assay synthesizes a large amount of by-product, an insoluble

* Correspondence to: Sahin, O., Department of Veterinary Microbiology and Preventive Medicine, Iowa State University, Ames, IA 50011, U.S.A.

e-mail: osahin@iastate.edu

(C)2012 The Japanese Society of Veterinary Science white precipitate of magnesium pyrophosphate, which can be judged visually by the appearance of a white precipitate, or fluorescence observed under UV with the addition of SYBR Green dye. The amplification reaction does not require a complex thermocycler; rather a simple water bath is sufficient for the entire process $[3,6,15]$.

The objective of the current study was to develop a LAMP assay specific for a particular $C$. jejuni clone in order to facilitate its rapid, sensitive and reliable detection and/or identification from clinical samples in conjunction with culture. Since this clone (named clone SA for sheep abortion) has been shown by our research team to be responsible for the vast majority of recent ovine abortions in the U.S. and is also implicated in a large number of current human infections [13], such an assay would be invaluable tool for both animal and public health studies.

\section{MATERIALS AND METHODS}

Campylobacter jejuni strains: The IA3902 strain was isolated by us from an aborted ovine fetus and characterized by pulsed-field gel electrophoresis (PFGE), multilocus sequence typing (MLST) and $c m p$ gene sequence typing [13]. It was further shown to be highly pathogenic in animal models compared with other strains [2]. This strain is a member of clone SA that is associated with the vast majority of recent sheep abortions in the U.S. The strains 81-176 [4] and NCTC 11168 [8] are of human origin and commonly used by many investigators for research purposes. Eight $C$. jejuni isolates (covering both SA clone and non-clonal strains as previously determined using PFGE and MLST) obtained from aborted ovine placentas or from feces of healthy sheep were also included. The clone SA 
Table 1. List of LAMP primers used in this study

\begin{tabular}{|c|c|c|c|c|c|}
\hline Strain & Target gene & $\begin{array}{l}\text { GenBank } \\
\text { accession no. }\end{array}$ & Primer & Sequence ( $5^{\prime}$ to $\left.3^{\prime}\right)$ & Gene location (bp) \\
\hline \multirow[t]{4}{*}{$\begin{array}{l}\text { C. jejuni } \\
\text { IA3902 }\end{array}$} & CJSA_1356 & СР001876.1 & FIP & $\begin{array}{l}\text { TTC TGG TGG AAA TGG TGC GGG CAT } \\
\text { TCA TTA AGC ATA GGG T }\end{array}$ & $\begin{array}{l}\text { 1179-1198 (F1c), } \\
1138-1157 \text { (F2) }\end{array}$ \\
\hline & & & BIP & $\begin{array}{l}\text { CCT GGC CAC AAA CTT TCC ACG CGT } \\
\text { TAA TTG ATT CTT TCT CTC AT }\end{array}$ & $\begin{array}{l}1199-1218(\mathrm{~B} 1 \mathrm{c}) \\
1255-1278(\mathrm{~B} 2)\end{array}$ \\
\hline & & & F3 & TTA GAC ATT ATA AGT TCA CGA GG & $1115-1137$ \\
\hline & & & B3 & CAG CTA AGA CCT GGT TGG & 1294-1311 \\
\hline
\end{tabular}

isolates were ID27, IA3433, IA975, IA2918, and SD6152 (all from sheep abortions); the non-clonal isolates were 2L10F3, 2L1F6, and 2L6F2 (all from feces of healthy sheep). Bacterial cultures were routinely grown on Mueller Hinton $(\mathrm{MH})$ agar in anaerobic jars under microaerobic conditions $(5 \%$ oxygen, $10 \%$ carbon dioxide, and $85 \%$ nitrogen) at $42^{\circ} \mathrm{C}$. Fresh cultures grown for $24 \mathrm{hr}$ were collected in $\mathrm{MH}$ broth and appropriate dilutions were made for further steps.

DNA extraction: Bacterial cultures put in phosphate buffered saline (PBS, Sigma-Aldrich, St. Louis, MO, U.S.A.) were boiled for $10 \mathrm{~min}$, frozen at $-20^{\circ} \mathrm{C}$ and thawed at room temperature, and then centrifuged at 13,000 $\mathrm{g}$ for $5 \mathrm{~min}$ at $4^{\circ} \mathrm{C}$. The supernatant was transferred to a new tube and used as the template DNA in the LAMP assay. In addition, a DNA purification kit (Wizard Genomic DNA Purification Kit, Promega Corporation, Madison, WI, U.S.A.) was used to extract genomic DNA from bacterial cultures when determining the sensitivity of the LAMP assay.

Design of primers for LAMP: A set of four specific primers was designed to target $C$. jejuni IA3902, whose complete genome sequence is available (GenBank accession no: CP001876.1 and CP001877.1). Briefly, a unique gene (CJSA_1356; part of the capsule locus, $1920 \mathrm{bp}, 639 \mathrm{aa}$ ) of IA $390 \overline{2}$ identified to be present only in IA3902 based on comparative genomics was selected for use as the LAMP target. The LAMP primers were designed using the PrimerExplorer V4 software program (http://primerexplorer. jp) as follows: Forward outer primer (F3), Backward outer primer (B3), Forward inner primer (FIP) and Backward inner primer (BIP). The sequences of the primers and their locations are shown in Table 1. All primers were synthesized by DNA Facility of Iowa State University.

$L A M P$ reaction: LAMP assay was performed with a Loopamp DNA Amplification Kit (Eiken Chemical Co., Ltd., Tokyo, Japan). The assay was carried out in a $25 \mu l$ total reaction volume containing $12.5 \mu \mathrm{l}$ of $2 \times$ reaction premix (supplied with the kit; including dNTPs), $6.5 \mu \mathrm{l}$ of distilled water, $1.6 \mu \mathrm{M}$ each of FIP and BIP, $0.2 \mu \mathrm{M}$ each of F3 and B3, $1.0 \mu l(8.0 \mathrm{U})$ of the Bst DNA polymerase (supplied with the kit), and $2.0 \mu l$ of template DNA. For controls, $2.0 \mu l$ of PC DNA (supplied with the LAMP kit) and $2.0 \mu \mathrm{l}$ of distilled water were used as template in the LAMP reactions as a positive and negative control, respectively. Reaction time was optimized by incubating the mixture for $20,30,40,50$, and $60 \mathrm{~min}$ at a pre-determined temperature $\left(63^{\circ} \mathrm{C}\right)$, while the reaction temperature was optimized by incubating the mixture at $60,61,62,63,64$, and $65^{\circ} \mathrm{C}$ at a pre-determined time $(60 \mathrm{~min})$. The reaction was terminated via heating at $80^{\circ} \mathrm{C}$ for $5 \mathrm{~min}$. LAMP products $(5 \mu l)$ were electrophoresed in $1.5 \%$ agarose gels containing SYBR Green I (Invitrogen Corporation, Carlsbad, CA, U.S.A.) to determine the optimal conditions.

Observation of LAMP results with naked eye and under $U V$ : The reaction mixture was checked for a white precipitation with naked eye, and visually detected for fluorescence under UV following the addition of $1.0 \mu \mathrm{l}$ of a 100 fold-diluted original SYBR Green I (Invitrogen) to the reaction tube.

Specificity of LAMP assay compared with conventional PCR: The specificity of the LAMP assay was first determined with pure cultures of IA3902, 81-176 and NCTC 11168 strains as templates prepared via the boiling method. In addition, eight sheep $C$. jejuni strains (described above) including isolates of clone SA and those of different genomic backgrounds were tested to further assess the specificity of the LAMP assay for detection of clone SA. The LAMP reactions were performed at $63^{\circ} \mathrm{C}$ for $60 \mathrm{~min}$. Conventional PCR was carried out in parallel using the same templates prepared via the boiling method. PCR primers (forward primer: 5'-TCCCATTTGGATGTTGTTGA-3'; backward primer: 5'-CAGAACCTGGCCACAAACTT-3') were designed from CJSA_1356 gene of IA3902 to give an expected size of 430 bp as the amplification product. The PCR assay was carried out in a $25 \mu l$ total reaction volume containing $2.5 \mu l$ of 10×Ex Taq Buffer (Takara, Fisher Scientific, Pittsburg, PA, U.S.A.), $0.2 \mathrm{mM}$ of each dNTP, $0.4 \mu \mathrm{M}$ each of CJSA_1356 gene detection forward primer and backward primer, 16.0 $\mu l$ distilled water, $0.5 \mu l$ of the TaKaRa Ex Taq ${ }^{T M}$ DNA polymerase, and $2.0 \mu l$ of template DNA. The PCR reaction was run in a thermocycler (Applied Biosystems 2720 Thermal Cycler) with the conditions as follows: an initial denaturation for $5 \mathrm{~min}$ at $94^{\circ} \mathrm{C}$ followed by 30 cycles of denaturation at $94^{\circ} \mathrm{C}$ for $30 \mathrm{sec}$, annealing at $54^{\circ} \mathrm{C}$ for $30 \mathrm{sec}$, and extension at $72^{\circ} \mathrm{C}$ for $30 \mathrm{sec}$, and a final 7 min extension at $72^{\circ} \mathrm{C}$. Both the LAMP and PCR products were electrophoresed in $1.5 \%$ agarose gels containing SYBR Green I (Invitrogen) and viewed with a UV transilluminator.

Sensitivity of the LAMP assay compared with PCR: An initial bacterial culture of IA3902 was diluted in 2-fold series and $100 \mu \mathrm{l}$ from each dilution was plated out onto four $\mathrm{MH}$ agar plates, of which 2 were used for DNA extraction and the other 2 were used for CFU counting following microaerobic incubation at $42^{\circ} \mathrm{C}$ for $24 \mathrm{hr}$. The total genomic DNA was extracted from bacterial cultures via a DNA purification kit (Promega), its concentration determined using a NanoDrop microscale spectrophotometer (NanoDrop Technologies, Wilmington, DE, U.S.A.), and directly 



Fig. 1. Optimization of the LAMP assay. (A) Determination of the optimal temperature: Lane M: 100 bp DNA ladder (Takara); lane 1-6: The LAMP reaction was carried out at $60,61,62,63,64$ and $65^{\circ} \mathrm{C}$, respectively; 7: positive control (supplied with the LAMP kit); 8: negative control (supplied with the LAMP kit). (B) Determination of the optimal reaction time: Lane M: 100 bp DNA ladder (Takara); lane 1-5: The LAMP reaction was carried out at 20, $30,40,50$ and $60 \mathrm{~min}$, respectively; 6 : positive control; 7: negative control. All products were electrophoresed in 1.5\% agarose gels containing SYBR Green I (Invitrogen).

used in subsequent reactions without further dilution. The sensitivity tests of the LAMP and PCR assays were both conducted in triplicate and the reaction was considered positive only when all the triplicates were positive. The detection limits were defined as the lowest DNA concentration or CFU of bacteria (in $25 \mu l$ total reaction volume), for which a positive reaction was observed. LAMP reaction was performed at $63^{\circ} \mathrm{C}$ for $60 \mathrm{~min}$. The reaction tubes were observed by both naked eye and under UV for the LAMP as well as SYBR Green I (Invitrogen) staining of final reaction mixtures $(5 \mu l)$ run in a $1.5 \%$ agarose gel for both the LAMP and the PCR products.

Application of LAMP to detect IA3902 in guinea pig and mice: Guinea pigs and mice were orally challenged by $C$. jejuni IA3902, 81-176 or NCTC 11168 strains. The animal use protocols were approved by the Institutional Animal Care and Use Committee of Iowa State University (1008-6650-P and 6-10-6973-M). A total of 38 samples were collected from guinea pig placenta $(n=1)$ and feces $(n=5)$ as well as from mice livers $(n=16)$ and blood $(n=16)$. The samples were stored at $4^{\circ} \mathrm{C}$ and processed within $24 \mathrm{hr}$ as described below. Fetus, uterus, placenta and liver samples were cut into 1-2 $\mathrm{mm}$ pieces, diluted in $\mathrm{MH}$ broth $(1: 10$, $\mathrm{w} / \mathrm{v})$, grinded via a blender and centrifuged at 2,000 rpm for $5 \mathrm{~min}$ at $4^{\circ} \mathrm{C}$. The supernatant was used for further steps. Fecal samples were placed in $\mathrm{MH}$ broth $(1: 10, \mathrm{w} / \mathrm{v})$ and centrifuged at $2,000 \mathrm{rpm}$ for $5 \mathrm{~min}$ at $4^{\circ} \mathrm{C}$. Supernatants of each sample were treated to extract the DNA via the boiling method described above and used directly as template $(2 \mu l)$ in the LAMP and PCR assays. In addition, $100 \mu l$ from each supernatant and whole blood were spread onto $\mathrm{MH}$ agar plates containing Campylobacter-specific selective agents and growth supplements (SR084E and SR117E; Oxoid), and incubated for $48 \mathrm{hr}$ as described above. Campylobacter-like colonies from the plates were collected in $\mathrm{MH}$ broth and treated as described above (the boiling method) for use as template in the LAMP assay as well as in the conventional PCR for comparison.

\section{RESULTS}

Optimized LAMP reaction: The result of IA3902-specific LAMP assay showed that target DNA could be amplified at $60,61,62,63,64$ and $65^{\circ} \mathrm{C}$, with the clearest DNA band being visualized at $63^{\circ} \mathrm{C}$ (Fig. 1A). Thus, $63^{\circ} \mathrm{C}$ was chosen for use as the optimal temperature for the assay. Although LAMP products could be detected as short as within $50 \mathrm{~min}$ at $63^{\circ} \mathrm{C}$ (Fig. 1B), the bands detected following the $60 \mathrm{~min}$ amplification reaction were sharper, and thus 60 min was chosen as the optimal time for amplification in the LAMP assay.

Detection of LAMP products with naked eye and under $U V$ : A white precipitate (due to formation of insoluble magnesium pyrophosphate as by-product in positive reactions) was observed with naked eye in IA3902 and positive control (provided with the kit) LAMP reaction tubes, but no obvious precipitate was seen in negative control (provided with the kit) LAMP reaction tube (Fig. 2A). Likewise, a fluorescence signal under UV light after the addition of SYBR Green I was detected in IA3902 and positive control LAMP reaction, while no obvious fluorescence emission was observed in negative control LAMP reaction tube (Fig. 2B). The results from the two independent detection methods were well-correlated and confirmed by gel electrophoresis (data not shown), and clearly indicated the appropriateness of the LAMP assay for further experiments undertaken in this study.

Specificity of the LAMP assay: To determine if the LAMP assay was specific for $C$. jejuni IA3902 strain only, it was tested on two different $C$. jejuni strains in parallel with a conventional PCR test. In the LAMP assay, only IA3902 gave a positive reaction as observed following the gel electrophoresis, and no DNA bands were detected from the reaction tubes containing 81-176 or NCTC 11168 as templates (Fig. 3A). In parallel, a 430 bp product (of CJSA 1356 gene of IA3902) was amplified only from IA3902 but not from the two other strains by conventional PCR (Fig. 3B). These results suggested that the LAMP assay may be specific for detection of $C$. jejuni strain IA3902. In addition, the LAMP assay was further tested on a number of clone SA isolates $(n=5)$ other than IA3902 and non-clonal $C$. jejuni isolates $(n=3)$ from sheep. The result (not shown) indicated that the LAMP assay was positive only with isolates belonging to clone SA (in agreement with the conventional PCR results), which may further suggest its suitability for specific detection of this particular sheep abortion clone of $C$. jejuni.

Sensitivity of LAMP assay: Multiple DNA bands in agarose gel electrophoresis, white precipitate with naked eye and fluorescence signal under UV were observed from the products of LAMP reaction with IA3902 genomic DNA templates from $16.3 \mathrm{nM}\left(2.2 \times 10^{5} \mathrm{cfu} / \mathrm{m} l\right)$ to $3.2 \times 10^{-2} \mathrm{nM}$ $\left(4.4 \times 10^{2} \mathrm{cfu} / \mathrm{ml}\right)$, but not from $1.6 \times 10^{-2} \mathrm{nM}\left(2.2 \times 10^{2}\right.$ $\mathrm{cfu} / \mathrm{ml}$ ) (Fig. 4A, Fig. 4B1 and Fig. 4B2). Similarly, the 430 bp amplicon of CJSA_1356 gene was detected from 16.3 $\mathrm{nM}\left(2.2 \times 10^{5} \mathrm{cfu} / \mathrm{m} l\right)$ to $3.2 \times 10^{-2} \mathrm{nM}\left(4.4 \times 10^{2} \mathrm{cfu} / \mathrm{m} l\right)$ of IA3902 DNA, but not from $1.6 \times 10^{-2} \mathrm{nM}\left(2.2 \times 10^{2} \mathrm{cfu} /\right.$ $\mathrm{m} l$ ) by conventional PCR (Fig. 4C). When the template was 


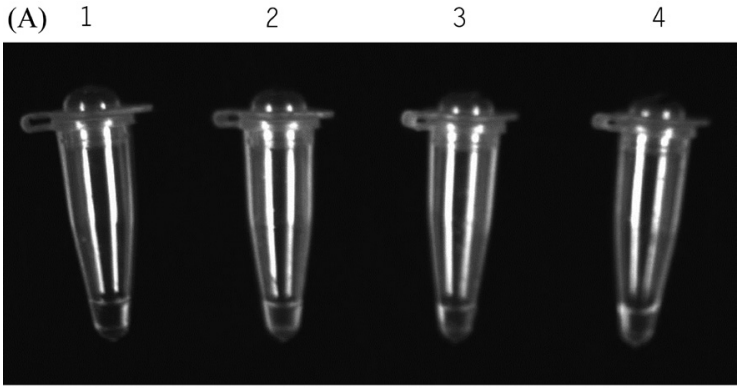

(B)

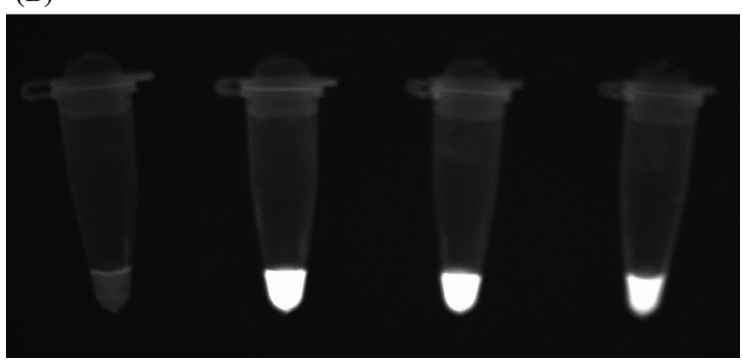

Fig. 2. Detection of LAMP products following amplification for $60 \mathrm{~min}$ at $63^{\circ} \mathrm{C}$. (A) white turbidity is visualized with naked eye as an indication of positive reaction due to formation of magnesium pyrophosphate precipitate; (B) fluorescence observed under UV after the addition of SYBR Green I (Invitrogen). Lane 1: negative control; 2: positive control; both 3 and 4: C. jejuni IA3902.

prepared via the boiling method, the detection limit of both the LAMP and conventional PCR was also $4.4 \times 10^{2} \mathrm{CFU} /$ $\mathrm{m} l$ in the final reaction volume of $25 \mu l$ (result not shown).

Application of LAMP to detect IA3902 in guinea pig and mice samples: Applicability of the LAMP assay to specifically detect and/or identify IA3902 was tested on samples from guinea pigs and mice that were experimentally infected with IA3902, 11168, or 81-176. When the LAMP (and regular PCR) was tested directly on tissue homogenates or fecal suspensions (prepared via the boiling method), none of the samples yielded a positive signal regardless of culture results (data not shown). Overall, cfu values from mouse blood $(\mathrm{n}=16)$ and liver $(\mathrm{n}=16)$ were quite low (less than $50 \mathrm{cfu} / \mathrm{m} l$ or g). Unexpectedly, cfu values from guinea pig feces $(n=5)$ and aborted placenta $(n=1)$ were also very low, being less than 10 cfu/g. Of the 20 samples yielding a positive culture result, 13 were from IA3902-infected animals. Colonies from all of the positive samples were tested with the LAMP and conventional PCR, and only those obtained from IA3902-infected animals $(n=13)$ gave a positive result with both assays, indicating the specificity of the LAMP for clone SA (Table 2).

\section{DISCUSSION}

Our published $[2,13]$ and ongoing studies have shown that clone SA has become predominant cause of Campylobacter-associated ovine abortions in the U.S and is a hyper-virulent pathogen in pregnant animals. In addition, our ongoing collaboration with Centers for Disease Control

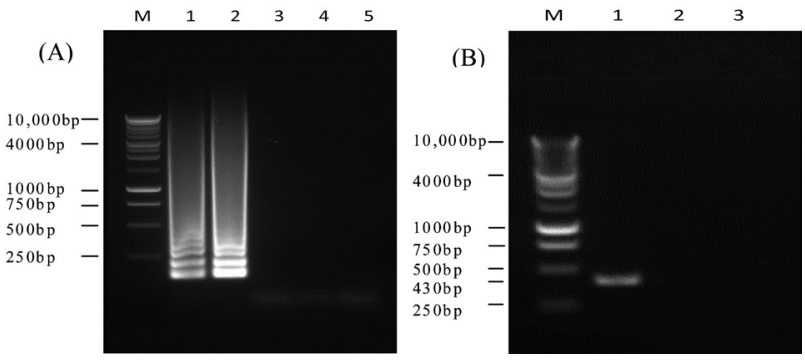

Fig. 3. Specificity of the LAMP assay as determined by comparison to conventional PCR. M: $1 \mathrm{~Kb}$ DNA ladder (Promega) (A) The LAMP reaction was carried out at $63^{\circ} \mathrm{C}$ for $60 \mathrm{~min}$. Lanes 1: positive control (as in Fig. 1); 2: IA3902; 3: 81-176; 4: NCTC 11168; 5: negative control (as in Fig. 1). (B) Conventional PCR. Lanes 1: IA3902; 2: 81-176; 3: NCTC 11168. All the products were electrophoresed in 1.5\% agarose gels containing SYBR Green I (Invitrogen).

and Prevention (CDC) has indicated that this clone is associated with an increasing number gastroenteritis cases in humans. Therefore, in this study, we sought to develop a simple and rapid assay for sensitive and specific detection and identification of this particular $C$. jejuni clone in order to better facilitate future epidemiological studies aimed at its control in both ruminants and humans. In comparison to conventional PCR, the LAMP assay developed here is shown to be as sensitive and specific for culture confirmation of clone SA, indicating its potential use for rapid and simpler identification purposes mainly.

A number of LAMP assays for Campylobacter have previously been developed for detection of different Campylobacter species in various sources including human diarrheal stool [16] and chicken meat samples [18], and for differentiation of closely related Campylobacter subspecies in pure culture $[17,19]$. A common conclusion from these studies is that the LAMP assay was faster and simpler than regular PCR and/or culture while being as sensitive and specific for the purpose of use and that it was thus a practical tool for surveillance and other epidemiological studies. Although it has not been reported to date, these studies also indicate the use of LAMP for highly specific detection of certain $C$. jejuni stains of interest. Therefore, we attempted at devising a LAMP assay specific for clone SA of $C$. jejuni via utilizing the complete genome sequence of IA3902 (a clone SA strain) by targeting a gene (CJSA_1356) uniquely present in this particular clone only.

When developing LAMP, usually a set of six LAMP primers are designed including one FIP (forward inner primer), one BIP (backward inner primer), one F3 (forward outer primer), one B3 (backward outer primer), one LF (loop forward) and one LB (loop backward). LF and LB primers can accelerate the LAMP reaction and the products can be detected as early as $20 \mathrm{~min}$ [7, 19]. However, in our study only a set of four specific primers was designed by targeting the unique gene of IA3902; neither LF nor LB primer could be designed probably due to sequence specific restrictions. Lack of these two primers may explain the observation that 


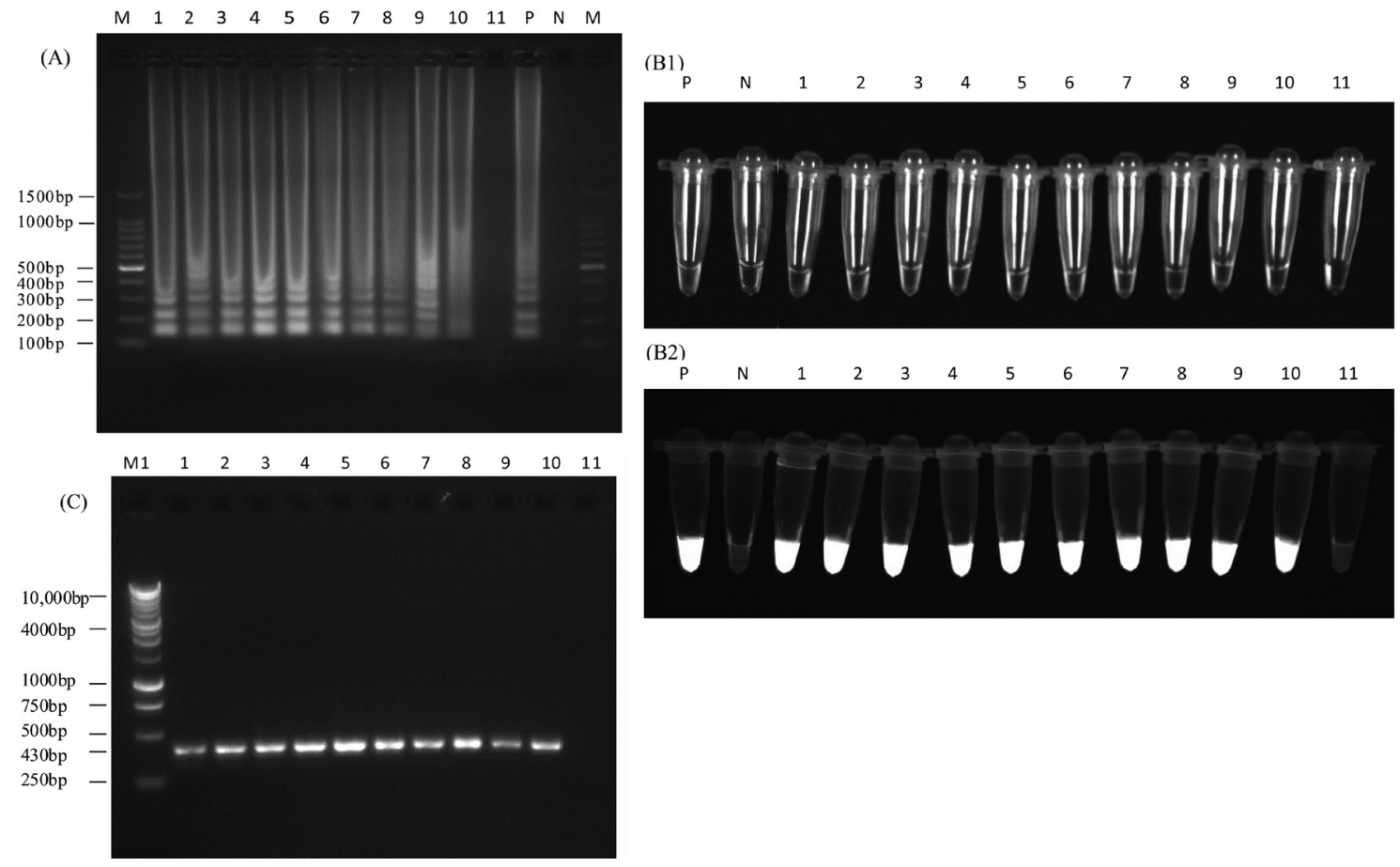

Fig. 4. Sensitivity of the LAMP assay for detection of $C$. jejuni IA3902 DNA as determined by gel electrophoresis (A) and with naked eye (B1) and fluorescence signal under UV (B2), and its comparison to that of conventional PCR (C). The LAMP reaction and conventional PCR reaction were carried out using 2-fold serial dilutions of IA3902 genomic DNA. For both $\mathrm{A}$ and $\mathrm{C}$, the reaction products were electrophoresed in $1.5 \%$ agarose gels containing SYBR Green I (Invitrogen). For all panels, the lane or tube designations are as follows: M: 100 bp DNA ladder (Takara); M1: 1 KB DNA ladder (Promega); 1: $16.3 \mathrm{nM}\left(2.2 \times 10^{5} \mathrm{cfu} / \mathrm{m} l\right) ; 2: 8.1 \mathrm{nM}\left(1.1 \times 10^{5} \mathrm{cfu} / \mathrm{ml}\right) ; 3: 4.1 \mathrm{nM}\left(5.7 \times 10^{4} \mathrm{cfu} / \mathrm{ml}\right) ; 4: 2.0 \mathrm{nM}\left(2.8 \times 10^{4} \mathrm{cfu} / \mathrm{m} l^{-1}\right) ; 5: 1.0$ $\mathrm{nM}\left(1.4 \times 10^{4} \mathrm{cfu} / \mathrm{m} l\right) ; 6: 0.5 \mathrm{nM}\left(7.2 \times 10^{3} \mathrm{cfu} / \mathrm{ml}\right) ; 7: 0.26 \mathrm{nM}\left(3.6 \times 10^{3} \mathrm{cfu} / \mathrm{ml}\right) ; 8: 0.13 \mathrm{nM}\left(1.8 \times 10^{3} \mathrm{cfu} / \mathrm{m} l\right) ; 9: 6.4 \times$ $10^{-2} \mathrm{nM}\left(8.8 \times 10^{2} \mathrm{cfu} / \mathrm{m} l\right) ; 10: 3.2 \times 10^{-2} \mathrm{nM}\left(4.4 \times 10^{2} \mathrm{cfu} / \mathrm{m} l\right) ; 11: 1.6 \times 10^{-2} \mathrm{nM}\left(2.2 \times 10^{2} \mathrm{cfu} / \mathrm{m} l\right)$; P: positive control (as in Fig. 1); N: negative control (as in Fig. 1).

the LAMP products could only be detected after $50 \mathrm{~min}$ of incubation in this study (Fig. 1B). However, we set the reaction time at $60 \mathrm{~min}$ in the LAMP assay in order to ensure positive detection of DNA templates of low concentrations.

A conventional PCR targeting the same unique gene (CJSA_1356) as the LAMP was used to determine the performance of the LAMP assay, which showed that the LAMP was as sensitive as the PCR assay when tested on either purified genomic DNA or boiled extract of C. jejuni colonies (Fig. 4). Similarly, the LAMP assay in comparison to the PCR was equally specific when tested with two laboratory strains of known genomic sequence (NCTC 11168 and 81-176; both lack CJSA_1356 homolog) (Fig. 3), and with eight clinical $C$. jejuni isolates (containing both clone SA and other strains) from ovine abortion cases and the intestine of healthy sheep (result not shown). It should be pointed out that although our results may indicate the specificity of the LAMP assay for clone SA, more Campylobacter strains (including clone $\mathrm{SA}$ and non-clonal isolates) from diverse sources need to be evaluated to firmly confirm this finding since relatively low number of strains $(n=11)$ were used in the current study to initially determine the specificity of the LAMP assay.

During the course of development of the LAMP assay, our research team was conducting challenge experiments with guinea pigs and mice for different purposes since these two species of animals are commonly used as model for sheep abortion and/or systemic infection [1, 2, 10]. Thus, we next evaluated the potential use of the LAMP in direct detection of clone SA from infected tissues and fecal samples. When the LAMP and PCR were tested directly on boiled extracts prepared from fecal or tissue homogenates, both tests failed to detect the organism in tissues and feces that were later confirmed to be infected via culture (result not shown). Culture results indicated that the cfu values were quite low in tested samples (less than $50 \mathrm{cfu} / \mathrm{m} l$ or $\mathrm{g}$ sample). These numbers are surprisingly low especially for the aborted guinea pig placenta, but it may be due to the fact that the samples were not processed immediately but were subjected to a storage (up to $24 \mathrm{hr}$ ) first. In the current study, no spiking experiments of uninfected tissues with known numbers $C$. jejuni cells were performed to determine the detection limit of the assay directly on clinical samples. It may also be that the LAMP assay would be more sensitive if used on templates prepared from infected samples via a commercial genomic DNA extraction kit. Future studies addressing these concerns including sample collection/storage conditions and DNA extraction methods are warranted since the use of the LAMP assay in detection of clone SA 
Table 2. Application of the LAMP assay for specific identification of C. jejuni IA3902 cultured from tissues of animals infected with different Campylobacter strains

\begin{tabular}{|c|c|c|c|c|}
\hline Sample & Strain & Culture $^{a)}$ & LAMP $^{\mathrm{a}, \mathrm{b})}$ & $\mathrm{PCR}^{\mathrm{a}, \mathrm{b})}$ \\
\hline \multirow{2}{*}{$\begin{array}{l}\text { Guinea pig placenta } \\
(\mathrm{n}=1)\end{array}$} & IA3902 (n=1) & $1 / 1$ & $1 / 1$ & $1 / 1$ \\
\hline & $\begin{array}{l}\text { Non-IA3902 } \\
(\mathrm{n}=0)\end{array}$ & $0 / 0$ & $0 / 0$ & $0 / 0$ \\
\hline \multirow{2}{*}{$\begin{array}{l}\text { Guinea pig feces } \\
(\mathrm{n}=5)\end{array}$} & IA3902 $(n=4)$ & $4 / 4$ & $4 / 4$ & $4 / 4$ \\
\hline & $\begin{array}{l}\text { Non-IA3902 } \\
(\mathrm{n}=1)\end{array}$ & $1 / 1$ & $0 / 1$ & $0 / 1$ \\
\hline \multirow{2}{*}{$\begin{array}{l}\text { Mice liver } \\
(\mathrm{n}=16)\end{array}$} & IA3902 $(n=3)$ & $3 / 3$ & $3 / 3$ & $3 / 3$ \\
\hline & $\begin{array}{l}\text { Non-IA3902 } \\
(\mathrm{n}=13)\end{array}$ & $4 / 13$ & $0 / 4$ & $0 / 4$ \\
\hline \multirow{2}{*}{$\begin{array}{l}\text { Mice blood } \\
(\mathrm{n}=16)\end{array}$} & IA3902 $(n=5)$ & $5 / 5$ & $5 / 5$ & $5 / 5$ \\
\hline & $\begin{array}{l}\text { Non-IA3902 } \\
(\mathrm{n}=11)\end{array}$ & $2 / 11$ & $0 / 2$ & $0 / 2$ \\
\hline
\end{tabular}

a) No. of positive samples / total no. of samples. b) Both the LAMP and conventional PCR were performed on bacterial colonies recovered from culture positive samples.

directly from clinical samples would greatly improve its applicability. When the LAMP tested on Campylobacter colonies on plates isolated from animals infected with different $C$. jejuni strains, only those samples originated from IA3902-infected animals gave a positive signal (Table 2). This finding indicated that in conjunction with culture the LAMP is suitable for specific identification of clone SA and that it may be used for rapid and simpler detection of clone SA in clinical samples such as aborted ovine material.

ACKNOWLEDGMENTS. This work was supported by the National Research Initiative Competitive Grants Program from the National Institute of Food and Agriculture at USDA (Grant No. 2010-65110-20419). Yan Luo was supported by a scholarship from the China Scholarship Council.

\section{REFERENCES}

1. Baqar, S., Bourgeois, A. L., Applebee, L. A., Mourad, A. S., Kleinosky, M. T., Mohran, Z. and Murphy, J. R. 1996. Murine intranasal challenge model for the study of Campylobacter pathogenesis and immunity. Infect. Immun. 64: 4933-4939. [Medline]

2. Burrough, E. R., Sahin, O., Plummer, P. J., Zhang, Q. J. and Yaeger, M. J. 2009. Pathogenicity of an emergent, ovine abortifacient Campylobacter jejuni clone orally inoculated into pregnant guinea pigs. Am. J. Vet. Res. 70: 1269-1276. [Medline] [CrossRef]

3. Fu, S. J., Qu, G. G., Guo, S. J., Ma, L., Zhang, N., Zhang, S. L., Gao, S. Y. and Shen, Z. Q. 2011. Applications of LoopMediated Isothermal DNA Amplification. Appl. Biochem. Biotechnol. 163: 845-850. [Medline] [CrossRef]

4. Hofreuter, D., Tsai, J., Watson, R. O., Novik, V., Altman, B., Benitez, M., Clark, C., Perbost, C., Jarvie, T., Du, L. and Galan, J. E. 2006. Unique Features of a Highly Pathogenic Campylobacter jejuni Strain. Infect. Immun. 74: 4694-4707. [Medline] [CrossRef]

5. Logan, J. M. J., Edwards, K. J., Saunders, N. A. and Stanley, J. 2001. Rapid identification of Campylobacter spp. by melting peak analysis of biprobes in real-time PCR. J. Clin. Microbiol. 39: 2227-2232. [Medline] [CrossRef]

6. Notomi, T., Okayama, H., Masubuchi, H., Yonekawa, T.,
Watanabe, K., Amino, N. and Hase, T. 2000. Loop-mediated isothermal amplification of DNA. Nucleic Acids Res. 28: e63 (i-vi). [Medline] [CrossRef]

7. Nagamine, K., Hase, T. and Notomi, T. 2002. Accelerated reaction by loop-mediated isothermal amplification using loop primers. Mol. Cell. Probes 16: 223-229. [Medline] [CrossRef]

8. Parkhill, J., Wren, B. W., Mungall, K., Ketley, J. M., Churcher, C., Basham, D., Chillingworth, T., Davies, R. M., Feltwell, T., Holroyd, S., Jagels, K., Karlyshev, A. V., Moule, S., Pallen, M. J., Penn, C. W., Quail, M. A., Rajandream, M. A., Rutherford, K. M., van Vliet, A. H. M., Whitehead, S. W. and Barrell, B. G. 2000. The genome sequence of the food-borne pathogen Campylobacter jejuni reveals hypervariable sequences. $\mathrm{Na}$ ture 403: 665-668. [Medline] [CrossRef]

9. Persson, S. and Olsen, K. E. P. 2005. Multiplex PCR for identification of Campylobacter coli and Campylobacter jejuni from pure cultures and directly on stool samples. J. Med. Microbiol. 54: 1043-1047. [Medline] [CrossRef]

10. Sultandosa, A. B., Bryner, J. H. and Foley, J. W. 1983. Pathogenicity of Campylobacter jejuni and Campylobacter coli strains in the pregnant guinea pig model. Am. J. Vet. Res. 44: 2175-2178. [Medline]

11. Sahin, O., Kobalka, P. and Zhang, Q. J. 2003a. Detection and survival of Campylobacter in chicken eggs. J. Appl. Microbiol. 95: 1070-1079. [Medline] [CrossRef]

12. Sahin, O., Zhang, Q. J. and Morishita, T. Y. 2003b. Detection of Campylobacter, pp. 183-193. In Microbial Food Safety in Animal Agriculture (Torrence, M. E. and Isaacson, R. E. eds.), Iowa State Press, Ames.

13. Sahin, O., Plummer, P. J., Jordan, D. M., Sulaj, K., Pereira, S., Austerman, S. R., Wang, L. P., Yaeger, M. J., Hoffman, L. J. and Zhang, Q. J. 2008. Emergence of a tetracycline-resistant Campylobacter jejuni clone associated with outbreaks of ovine abortion in the United States. J. Clin. Microbiol. 46: 1663-1671. [Medline] [CrossRef]

14. Wang, H., Farber, J. M., Malik, N. and Sanders, G. 1999. Improved PCR detection of Campylobacter jejuni from chicken rinses by a simple sample preparation procedure. Int. J. Food Microbiol. 52: 39-45. [Medline] [CrossRef]

15. Yamazaki, W., Seto, K., Taguchi, M., Ishibashi, M. and Inoue, K. 2008a. Sensitive and rapid detection of cholera toxinproducing Vibrio cholerae using a loopmediated isothermal amplification. BMC Microbiol. 8: 94. [Medline] [CrossRef]

16. Yamazaki, W., Taguchi, M., Ishibashi, M., Kitazato, M., Nukina, M., Misawa, N. and Inoue, K. 2008b. Development and evaluation of a loop-mediated isothermal amplification assay for rapid and simple detection of Campylobacter jejuni and Campylobacter coli. J. Med. Microbiol. 57: 444-451. [Medline] [CrossRef]

17. Yamazaki, W., Taguchi, M., Ishibashi, M., Nukina, M., Misawa, N. and Inoue, K. 2009a. Development of a loop-mediated isothermal amplification assay for sensitive and rapid detection of Campylobacter fetus. Vet. Microbiol. 136: 393-396. [Medline] [CrossRef]

18. Yamazaki, W., Taguchi, M., Kawai, T., Kawatsu, K., Sakata, J., Inoue, K. and Misawa, N. 2009b. Comparison of loop-mediated isothermal amplification assay and conventional culture methods for detection of Campylobacter jejuni and Campylobacter coli in naturally contaminated chicken meat samples. Appl. Environ. Microbiol. 75: 1597-1603. [Medline] [CrossRef]

19. Yamazaki, W., Taguchi, M. and Misawa, N. 2010. Development of loop-mediated isothermal amplification and PCR assays for rapid and simple detection of Campylobacter fetus subsp. venerealis. Microbiol. Immunol. 54: 398-404. [Medline] 